\title{
UJI HEDONIK PRODUK BOREH PENURUN DEMAM DARI BAWANG MERAH (Allium cepa L.) DAN KULIT BATANG PULE (Alstonia scholaris L.)
}

\section{HEDONIC TEST PRODUCTS BOREH REDUCING FEVER FROM RED ONION (Allium cepa L.) AND PULE STEM LEATHER (Alstonia scholaris L.)}

\author{
NI PUTU SINTA MAHASUARI ${ }^{\bullet}$, NI KADEK CORNELIA AYU TRISNA ${ }^{1}$, \\ NI KADEK KARYAWATI ${ }^{1}$, ANDREW BORNEO SALIAN PAWARRANGAN ${ }^{1}$ \\ ${ }^{1}$ Program Studi Farmasi, Fakultas MIPA, Universitas Udayana, Jimbaran, Badung, Bali, Indonesia
}

\begin{abstract}
Abstrak: Bawang merah merupakan salah satu bumbu masakan yang memiliki khasiat dibidang kesehatan yakni sebagai penurun demam. Bawang merah mengandung florogusin, sikloalanin, metialin, dan kaemferol yang berperan untuk menurunkan demam. Selain bawang merah kulit batang pule juga memiliki khasiat sebagai penurun demam dan obat tekanan darah tinggi. Demam merupakan suatu keadaan suhu tubuh diatas normal sebagai akibat peningkatan pusat pengatur suhu dihipotalamus. Pemberian terapi obat tradisional pada pengobatan demam di Indonesia beragam, salah satunya pemberian jamu. Campuran dari tanaman bawang merah, kulit batang pule, air jeruk nipis, minyak kelapa, serbuk cendana, garam yang dibuat dalam bentuk sediaan boreh dapat mengobati demam. Penggunaan obat tradisional dengan cara dibalurkan seperti boreh akan mempermudah pengaplikasiannya pada bayi atau anak-anak, serta orang yang sulit minum obat. Penggunaan obat pada kulit juga dapat memberikan rasa tidak nyaman karena teksturnya yang kasar, ukuran partikelnya kurang halus, serta kemampuannya untuk menempel pada kulit. Sehingga untuk mengetahui kenyamanan dari boreh perlu dilakukan uji Hedonik. Uji hedonik dilakukan dengan cara menyebarkan kuesioner yang memuat beberapa indikator dan tingkat kesukaan kepada beberapa responden. Berdasarkan hasil uji hedonik boreh Bonupa (boreh penurun panas) menunjukkan setengah jumlah responden menyukai rasa yang timbul saat boreh Bonupa dioleskan pada kulit, tetapi sebagian lagi ada yang tidak menyukainya karena adanya kesan berminyak yang membuat responden kurang nyaman saat menggunakannya.
\end{abstract}

Kata kunci: bawang merah, boreh, demam, jamu, kulit batang pule.

Abstract: Shallot is one of the spices that has health properties as a fever-lowering agent. Shallots contain fluorine, cycloalanin, metialin, and kaemferol which play a role in reducing fever. Besides onion, the skin of the pule stem also has efficacy as a fever-lowering and high blood pressure medicine. Fever is a state of body temperature above normal as a result of an increase in the temperature control center of the hypothalamus. The provision of traditional medicine therapy in the treatment of fever in Indonesia is diverse, one of which is the provision of herbal medicine. A mixture of onion plants, pule bark, lime juice, coconut oil, sandalwood powder, salt made in the form of boreh can treat fever. The use of traditional medicines by being channeled like boreh will facilitate its application in infants or children, as well as people who have difficulty taking medicine. The use of drugs on the skin can also provide discomfort because of its rough texture, particle size is less smooth, and its ability to stick to the skin. To understand the convinience used of boreh in hedonic test needs to be done. The hedonic test was carried out by distributing questionnaires containing several indicators and the level of preference to several respondents. Based on the hedonic test results showed half the number of respondents liked the taste that arises when Bonupa herbal is applied to the skin, but some others do not like it because of the greasy impression that makes respondents less comfortable when using it.

Keywords: boreh, fever, herb, pule bark, shallots.

\section{PENDAHULUAN}

Demam merupakan suatu keadaan suhu tubuh diatas normal sebagai akibat peningkatan pusat pengatur suhu dihipotalamus (Wardiyah, dkk., 2016). Demam juga merupakan gejala dari suatu penyakit lain yang dapat membahayakan jiwa. Hampir semua kelompok sosial beranggapan bahwa demam adalah suatu hal yang membahayakan dan perlu ditangani dengan menurunkan demam segera mungkin. Hal ini karena dampak yang dapat ditimbulkan oleh demam sangat berbahaya, seperti dehidrasi, pneumonia berat, penyakit kardiovaskular, kerusakan neurologis hingga kejang (Rini dan Abra, 2013). Pemberian terapi obat tradisional pada pengobatan demam di Indonesia beragam, salah satunya pemberian obat

•email korespondensi: sintamahasuari0916@gmail.com 
tradisional. Pada umumnya obat tradisional ini dapat berupa serbuk, pil, parem, seduhan, ataupun minyak yang berisi seluruh bahan tanaman yang menjadi penyusun jamu tersebut (Mulyani, dkk., 2016).

Menurut buku Guidelines for The Use of Herbal Medicines in Family Health Care, campuran dari tanaman bawang merah, kulit batang pule, air jeruk nipis, minyak kelapa, serbuk cendana, garam yang dibuat dalam bentuk sediaan parem dapat mengobati demam. Boreh adalah obat tradisional Bali yang penggunaanya seperti lulur dan biasanya digunakan sebagai penghangat tubuh. Boreh dapat disamakan dengan parem, berbentuk serbuk halus, dan dalam penggunaannya dicampur dengan cairan (air, cuka, arak, atau alkohol) (Juniari, dkk., 2017).

Bawang merah (Allium cepa L.) yang termasuk ke dalam famili liliaceae ini merupakan herba yang memiliki umbi berlapis. Umbi bawang merah tersebut dimanfaatkan sebagai bumbu masakan dan pengobatan. Kandungan florogusin, sikloaliin, metialiin, dan kaemferol dalam bawang merah dapat menurunkan suhu tubuh (Cahyaningrum, 2017). Untuk obat penurun panas dipakai \pm 20 gram umbi lapis Allium cepa, dicuci dan diparut. Hasil parutan dicampur dengan 1 sendok makan minyak kelapa, dibalurkan pada badan (Hutapea, 2000). Kulit batang pule berasal dari pohon pule (Alstonia scholaris L.) yang termasuk ke dalam famili Apocynaceae. Kulit batang pule mengandung senyawa flavonoid, saponin, dan polifenol. Secara empiris penggunaan oleh masyarakat dengan cara direbus, bertujuan untuk mendapatkan sari tanaman yang berkhasiat sebagai antimalaria. Namun di satu sisi cara rebusan dapat juga mempengaruhi kandungan zat aktif karena ada zat tertentu yang dapat mengalami kerusakan akibat perebusan dengan suhu yang tinggi. Kulit batang pule juga berkhasiat sebagai obat demam dan obat tekanan darah tinggi (Hutapea, 2000).

\section{METODE PENELITIAN}

\section{Bahan}

Bawang merah (Allium cepa L.), kulit batang pule (Alstonia scholaris L.), Boreh Bonupa

\section{Alat}

Pisau, talenan, ayakan mesh no. 60, mortir dan stamper, dan labu ukur, kuesioner.

\section{Cara Kerja \\ Preparasi Bahan}

Umbi bawang merah dikupas, dicuci, dipotong kecil dan ditumbuk. Kulit batang pule dicuci, dipotong kecil, dikeringkan, dihaluskan, dan diayak dengan ayakan no 60. Jeruk nipis diperas dan dihilangkan bijinya.

\section{Pembuatan Boreh Instan}

Bawang merah digunakan sebanyak $30 \mathrm{~g}$ dikupas dari kulitnya, lalu dicuci dengan air mengalir dan ditiriskan, kemudian dicincang. Bawang merah yang telah dicincang dicampurkan dan diremasremas dalam minyak kelapa sebanyak 1 sendok makan (15 mL), didiamkan selama 15 menit hingga minyak kelapa menjadi berbau bawang, lalu dipisahkan cincangan bawang dari minyak, sedangkan bagian minyaknya ditandai sebagai minyak bawang. Kulit batang pule digunakan sebanyak 1 ruas jari telunjuk atau kurang lebih $15 \mathrm{~g}$ dicuci lalu dipotong-potong menjadi bentuk yang lebih kecil, lalu dikeringkan dengan oven pada suhu $60^{\circ} \mathrm{C}$, lalu setelah kering diblender hingga berbentuk serbuk. Jeruk nipis digunakan sebanyak 1 buah yang dicuci terlebih dahulu, kemudian diperas dan diambil air perasannya sebanyak $5 \mathrm{~mL}$. Disiapkan serbuk kayu cendana sebanyak $3 \mathrm{~g}$ dan garam sebanyak $2 \mathrm{~g}$, kemudian kedua bahan tersebut dicampurkan dengan serbuk kulit batang pule hingga homogen dan menjadi berupa campuran serbuk. Campuran serbuk tersebut dicampurkan dengan air perasan jeruk nipis, diaduk hingga homogen. Setelah itu dimasukkan minyak bawang sedikit demi sedikit kedalam campuran bahan sebelumnya dengan sambil diaduk hingga homogen dan berbentuk seperti boreh. Kemudian boreh tersebut dimasukkan kedalam pot boreh untuk dikemas.

\section{Pembuatan Boreh Segar}

Bawang merah dikupas, dicuci dan ditimbang sebanyak 30 gram. Bawang dimasukan kedalam $10 \mathrm{~mL}$ minyak kelapa dan diremas-remas, kemudian ditambahkan 15 gram kulit pule yang telah ditumbuk, dan 7,5 air jeruk nipis setelah itu diaduk hingga rata. Ditambahkan 2 gram garam dan diaduk hingga rata

\section{Uji Hedonik}

Pengujian hedonik atau kesukaan terhadap sediaan boreh yaitu dengan mengisi angket uji hedonik formulasi segar dan instan dengan 60 responden disalah satu perguruan tinggi. Pada angket terdapat indikator kepuasan yakni warna, aroma, tekstur, dan kemasan (boreh instan) yang dinilai dengan kategori sangat tidak suka, tidak suka, suka, dan sangat suka.

Metode kuantitatif dengan instrument kuesioner merupakan metode yang digunakan dalam penelitian ini. Skala pengukuran yang digunakan yaitu sangat tidak suka (STS), tidak suka (TS), netral 
(N), Suka (S), dan sangat suka (SS). Rumus yang digunakan untuk menghitung \% kesukaan yakni:

$\%$ kesukaan $=\frac{\text { frekuensi }}{\text { jumlah responden }} \times 100$

\section{HASIL DAN PEMBAHASAN}

Jamu merupakan warisan budaya bangsa Indonesia, berupa ramuan bahan tumbuhan obat, sudah digunakan secara turun temurun yang terbukti aman dan mempunyai manfaat bagi kesehatan. Jamu digunakan untuk menjaga kesehatan, kebugaran dan kecantikan serta dapat membantu pemulihan kesehatan dan pencegahan penyakit. Mutu dari sediaan jamu adalah harus diolah sesuai dengan kaidah cara pembuatan jamu yang baik. Pembuatan jamu harus melakukan pemilihan bahan baku dengan mutu yang baik. Salah satu jenis sediaan jamu yang populer dikalangan masyarakat adalah boreh atau parem. Parem atau boreh merupakan sediaan padat atau cair obat tradisional yang terbuat dari serbuk simplisia dan atau ekstrak dan digunakan sebagai obat luar. Bahan baku yang baik adalah bahan baku yang bebas dari hama penyakit, cukup umur, bebas dari cemaran bahan seperti tanah, pasir dan rumput, serta bagian tumbuhan yang tepat adalah rimpang, kulit batang, daun, bunga, biji, buah, herba. Jamu terdiri beberapa bahan yaitu bahan aktif utama berkhasiat (BAUK), bahan aktif pendukung khasiat (BAPK), bahan tambahan (bahan pewarna, bahan penambah aroma, bahan pengisi, bahan penambah rasa), dan bahan pengantar. Ada pun bahan yang digunakan untuk membuat boreh penurun demam yakni bawang merah (Allium cepa L.) sebagai BAUK, air jeruk nipis (Citrus aurantifolia) dan kulit batang pule (Alstonia scholaris) sebagai BAPK, virgin of coconut oil (VCO) sebagai pembawa, serbuk cendana (Santalum album) sebagai korigen odoris, dan garam sebagai pengawet.

Bawang merah merupakan tanaman yang secara empiris digunakan untuk menurunkan demam (antipiretik). Secara ilmiah bawang merah yang digunakan dengan cara dikompres dapat mneurunkan panas karena mengandung senyawa Allylcysteine sulfoxide (Aliin). Antipiretik bekerja secara sentral menurunkan pusat pengatur tubuh di hipotalamus, yang diikuti respon fisiologis termasuk penurunan produksi panas, peningkatan aliran darah ke kulit, serta peningkatan pelepasan panas melalui kulit dengan radiasi, konveksi, dan penguapan (Cahyaningrum dkk., 2017). Bawang merah yang dibalurkan pada kulit dapat berperan sebagai penurun demam dengan metode konduksi dan evaporasi. Metode konduksi adalah metode penghantaran perpindahan panas dengan sentuhan langsung melalui evaporasi (penguapan). Pada penelitian ini bawang merah digunakan sebagai bahan berkhasiat utama yang digunakan dengan cara dibalurkan pada kulit dalam bentuk sediaan boreh.

Penggunaan obat tradisional dengan cara dibalurkan seperti boreh akan mempermudah pengaplikasiannya pada bayi atau anak-anak, serta orang yang sulit minum obat. Penggunaan obat pada kulit juga dapat memberikan rasa tidak nyaman karena teksturnya yang kasar, ukuran partikelnya kurang halus, serta kemampuannya untuk menempel pada kulit. Sehingga untuk mengetahui kenyamanan dari boreh campuran bawang merah dengan kulit batang pule, jeruk nipis, kayu cendana, VCO, dan garam perlu dilakukan uji Hedonik.

Uji hedonik merupakan pengujian untuk mengungkapkan tanggapan pribadi yaitu beberapa kesan yang berhubungan dengan kesukaan atau tanggapan senang atau tidaknya terhadap sifat sensori atau kualitas sediaan (Dewi dan Lestari, 2016). Uji hedonik dilakukan dengan cara menyebarkan kuesioner yang memuat beberapa indikator dan tingkat kesukaan kepada beberapa responden yang ditemukan di lingkungan salah satu perguruan tinggi. Setelah ditawarkan untuk mencoba produk dan memberitahukan keunggulan produk, responden kemudian diberikan waktu untuk mengisi kuesioner dan memberitahukan kesan dan pesan terkait produk jamu yang dicoba. Adapun pengujian hedonik yang telah dilakukan yaitu uji hedonik terhadap aroma, warna, konsistensi, wadah, kemasan sekunder, stiker, rasa setelah dioleskan, serta penilaian secara keseluruhan terhadap produk jamu penurun panas berbentuk boreh. Produk jamu penurun demam yang digunakan secara topikal diharapkan memiliki aroma yang khas yang mampu membuat penggunanya merasakan nyaman dan relax.

Tabel 1. Hasil Uji Hedonik Boreh Segar dengan Indikator Aroma, Warna, dan Konsistensi

\begin{tabular}{|c|c|c|c|c|c|c|c|c|}
\hline \multirow{3}{*}{$\begin{array}{l}\text { Ting } \\
\text { kat } \\
\text { Kesu } \\
\text { kaan }\end{array}$} & \multicolumn{8}{|c|}{ Indikator } \\
\hline & \multicolumn{2}{|c|}{ Aroma } & \multicolumn{2}{|c|}{ Warna } & \multicolumn{2}{|c|}{ Konsistensi } & \multicolumn{2}{|c|}{$\begin{array}{c}\text { Produk } \\
\text { Secara } \\
\text { Keseluruhan }\end{array}$} \\
\hline & $\mathrm{F}$ & $\%$ & $\mathrm{~F}$ & $\%$ & $\mathrm{~F}$ & $\%$ & $\mathrm{~F}$ & $\%$ \\
\hline STS & 1 & 3,3 & 1 & 3,3 & 1 & 3,3 & 1 & 3,3 \\
\hline TS & 3 & 10 & 1 & 3,3 & 0 & 0 & 0 & 0 \\
\hline B & 5 & 16,6 & 8 & 26,6 & 7 & 23,3 & 6 & 20 \\
\hline $\mathbf{S}$ & 16 & 53,3 & 18 & 60 & 18 & 60 & 16 & 53,3 \\
\hline SS & 5 & 16,6 & 2 & 6,6 & 4 & 13,3 & 7 & 23,3 \\
\hline $\begin{array}{c}\text { Juml } \\
\text { ah }\end{array}$ & 30 & 100 & 30 & 100 & 30 & 100 & 30 & 100 \\
\hline
\end{tabular}


Tabel 2. Hasil Uji Hedonik Boreh Instan dengan Indikator Aroma, Warna, dan Konsistensi

\begin{tabular}{ccccccc}
\hline \multirow{2}{*}{$\begin{array}{c}\text { Tingkat } \\
\text { Kesukaan }\end{array}$} & \multicolumn{2}{c}{ Aroma } & \multicolumn{2}{c}{ Warna } & \multicolumn{2}{c}{ Konsistensi } \\
\cline { 2 - 7 } & F & $\%$ & F & $\%$ & F & $\%$ \\
\hline STS & 1 & 3,3 & 1 & 3,3 & 0 & 0 \\
TS & 3 & 10 & 1 & 3,3 & 1 & 3,3 \\
B & 7 & 23,3 & 6 & 20 & 9 & 30 \\
S & 13 & 43,3 & 20 & 66,6 & 15 & 50 \\
SS & 7 & 23,3 & 4 & 13,3 & 6 & 20 \\
Jumlah & 30 & 100 & 30 & 100 & 30 & 100 \\
\hline
\end{tabular}

Tabel 3. Hasil Uji Hedonik dengan Indikator Wadah, Kemasan Sekunder dan Stiker

\begin{tabular}{|c|c|c|c|c|c|c|}
\hline \multirow{3}{*}{$\begin{array}{c}\text { Tingkat } \\
\text { Kesukaan }\end{array}$} & \multicolumn{6}{|c|}{ Indikator } \\
\hline & \multicolumn{2}{|c|}{ Aroma } & \multicolumn{2}{|c|}{ Warna } & \multicolumn{2}{|c|}{ Konsistensi } \\
\hline & $\mathrm{F}$ & $\%$ & $\mathrm{~F}$ & $\%$ & $\mathrm{~F}$ & $\%$ \\
\hline STS & 0 & 0 & 1 & 3,3 & 0 & 0 \\
\hline TS & 1 & 3,3 & 0 & 0 & 1 & 3,3 \\
\hline B & 5 & 16,6 & 8 & 26,6 & 6 & 20 \\
\hline $\mathbf{S}$ & 17 & 56,6 & 16 & 53,3 & 15 & 50 \\
\hline SS & 9 & 30 & 6 & 20 & 9 & 30 \\
\hline Jumlah & 30 & 100 & 30 & 100 & 30 & 100 \\
\hline \multicolumn{7}{|c|}{ Keterangan: } \\
\hline STS $=S$ & \multicolumn{6}{|c|}{ = Sangat Tidak Suka } \\
\hline $\mathrm{TS}$ & \multicolumn{6}{|c|}{$=$ Tidak Suka } \\
\hline$=\mathrm{I}$ & \multicolumn{6}{|c|}{$=$ Biasa } \\
\hline$=\leqq$ & \multicolumn{6}{|c|}{$=$ Suka } \\
\hline$=S$ & \multicolumn{6}{|c|}{$=$ Sangat Suka } \\
\hline
\end{tabular}

Berdasarkan hasil uji hedonik pada tabel 1 dan 2, dapat diketahui bahwa setengah dari jumlah repsonden menyukai aroma dari boreh segar maupun boreh instan. Persentase responden yang tidak menyukai aroma boreh disebabkan karena tidak menyukai aroma dominan yaitu aroma bawang yang merupakan BAUK dari boreh. Warna dari boreh Bonupa yang digunakan secara topikal disukai oleh setengah dari jumlah responden, tetapi ada yang tidak menyukai warna boreh Bonupa karena warnanya kurang menarik. Pada tabel 2. Menunjukkan bahwa setengah dari jumlah responden menyukai konsistensi dari boreh Bonupa karena teksturnya yang tidak terlalu padat dan tidak terlalu encer, sehingga nyaman digunakan pada kulit serta cepat menyerap pada kulit.

Berdasarkan tabel 3, evaluasi hedonik terhadap kemasan baik itu wadah, kemasan sekunder, dan stiker dari boreh Bonupa menunjukan bahwa setengah dari jumlah responden menyukai kemasannya. Beberapa responden yang tidak suka disebabkan karena kurang menariknya tampilan kemasan serta kurang praktisnya kemasan yang mempengaruhi proses penggunaan produk nantinya.
Setengah jumlah responden menyukai rasa yang timbul saat boreh Bonupa dioleskan pada kulit, tetapi sebagian lagi ada yang tidak menyukainya karena adanya kesan berminyak yang membuat responden kurang nyaman saat menggunakannya. Berdasarkan indikator-indikator tersebut, diketahui bahwa setengah dari jumlah responden menyukai produk boreh Bonupa secara keseluruhan. Adanya beberapa kritik dan saran dari responden terkait produk boreh Bonupa bermanfaat dalam meningkatkan kualitas dari boreh Bonupa nantinya.

\section{SIMPULAN}

Hasil evaluasi dengan uji hedonik menunjukkan setengah jumlah responden menyukai rasa yang timbul saat boreh Bonupa dioleskan pada kulit, tetapi sebagian lagi ada yang tidak menyukainya karena adanya kesan berminyak.

\section{DAFTAR PUSTAKA}

Cahyaningrum, E. D. (2017): Pengaruh kompres bawang merah terhadap suhu tubuh anak demam. Prosiding: Seminar Nasional dan Presentasi Hasil-Hasil Penelitian Pengabdian Masyarakat.

Dewi, I. K., \& Lestari, T. (2016). Formulasi Dan Uji Hedonik Serbuk Jamu Instan Antioksidan Buah Naga Super Merah (Hylocereus Costaricensis) Dengan Pemanis Alami Daun Stevia (Stevia Rebaudiana Bertoni M.). Interest: Jurnal Ilmu Kesehatan, 5(2), 149156.

Hutapea, J. R. (2000): Inventaris tanaman obat indonesia (I) Jilid 1. Departemen Kesehatan dan Kesejahteraan Sosial RI Badan Penelitian dan Pengembangan Kesehatan. Jakarta.

Juniari, P. D.A., Kriswiyanti. E., Sudiartawan. P. (2017): Tumbuhan bahan loloh dan boreh di Kelurahan Kawan, Kecamatan Bangli, Kabupaten Bangli. Seminar Nasional Fakultas MIPA UNHI Penguatan dan Pengajaran Biologi Sebagai Ilmu Dasar.

Mulyani, H., Widyastuti, S. H., Ekowati, V. I. (2016): Tumbuhan herbal sebagai jamu pengobatan tradisional terhadap penyakit dalam serat primbon jampi jawi jilid I. Jurnal Penelitian Humaniora. 21 (2): 73-91. 
Rini, E. S., dan Abra W, I W. P. A. (2013). Pengaruh Pemberian Minyak Kelapa Dengan Air Jeruk Nipis Terhadap Penurunan Suhu Tubuh Pada Anak Usia 1-3 Tahun Dengan Indikasi Febris Di Desa Salamet Kabupaten Turen. Biomed Science, 1(1), 15-21.

Wardiyah, A. dkk. 2016. Perbandingan Efektifitas Pemberian Kompres Hangat dan Tepid Sponge Terhadap Penurunan Suhu Tubuh Anak yang Mengalami Demam di Ruang Alamanda RSUD dr. H. Abdul Moeloek Provinsi Lampung Tahun 2015, 36-44. 